\title{
Heterosis and Inbreeding Depression in Linseed (Linum usitatissimum L.)
}

\author{
Aarti Sharma , Akanksha Srivastava and M.P. Chauhan \\ Department of Genetics and Plant Breeding, Narendra Deva University of Agriculture and \\ Technology, Faizabad-224 229, UP, India \\ *Corresponding author
}

\section{A B S T R A C T}

Analysis for heterosis in linseed (Linum usitatissimum L.) was carried out for 11 metric traits in linseed using four crosses viz., NDL 2004-05 x GS-234(cross I), NDL 2004-05 x

Keywords

Heterosis, Linseed, Inbreeding depression

Article Info

Accepted:

07 January 2018

Available Online:

10 February 2018
A-95B (cross II), NDL 2004-05 x TL-27(cross III) and NDL 2004-05 x TL-11(cross IV) developed under generation mean analysis. For days to $50 \%$ flowering (cross I, II and IV); days to maturity (cross I); plant height (cross I and III); number of primary branches per plant (cross I, II and III); number of capsules per plant (cross II and III); number of seeds per capsule (cross II and III); biological yield (cross II and IV); harvest index (cross II); and seed yield per plant (cross III) had significant or highly significant and positive standard heterosis, heterobeltiosis, mid-parent heterosis and inbreeding depression. Nature and magnitude of heterosis and inbreeding depression varied with crosses, characters as well as environments. Considering the very high degree of heterosis in desirable direction and presence of non-additive genetic variance for yield and yield contributing components; Cross II (NDL-2004-05 x A-95 B) and cross III (NDL-2004-05 x TL-27) were identified better specific cross combination to be used for exploitation of heterosis.

\section{Introduction}

Linseed, a self-pollinated, is being raised for both oil and fiber. Principally, linseed oil is used more in agro based industries as a lubricant for the manufacture of paint and varnish, oil- cloth, printing, lithographic inks, leather finishing, plasticizers, pharmaceutical products etc. than an edible oil. Linseed crop is of great importance but still its production is comparatively low. So, to increase yield a detailed investigation for the presence of heterosis in terms of standard heterosis, heterobeletosis and heterosis over mid parent were carried out in the present study. Similar kind of work on heterosis in linseed have also been reported by, Saraswat et al., (1993); Ratnaparkhi et al., (2004); Sharma et al., (2005). The estimates of heterosis over standard linseed variety (Hira), better parent and mid parent were calculated for four F1s on 11 metric traits to assess their genetic potential as breeding material. Rao et al., (2001) studied heterosis and inbreeding depression for 10 traits and found heterosis in either direction for most of the characters. Information about various aspects of heterosis for yield and yield attributing traits may be useful in providing further clues for exploitation of heterosis in linseed. Kumar et al., (2014) studied the effect of heterosis in different genotypes of linseed for different characters. 
Heterosis breeding can lead to breakthrough in yield in several crop plants including both self and cross-pollinated crop, with such objective study on heterosis for economically important characters had been done in this experiment, to develop high yielding hybrids and assess more information about various aspects of heterosis for yield and yield attributing traits

\section{Materials and Methods}

The experimental materials for the present investigation comprised of the parents $\left(\mathrm{P}_{1}\right.$ and $\left.\mathrm{P}_{2}\right)$, the $\mathrm{F}_{1} \mathrm{~s}, \mathrm{~F}_{2} \mathrm{~S}$ and back crosses $\left(\mathrm{BC}_{1}\right.$ and $\mathrm{BC}_{2}$ ) of each of the four crosses viz., NDL2004-05 X GS-234, NDL-2004-05 X A-95 B, NDL2004-05 X TL-27, NDL- 2004-05 X TL11.During 2013-14, seeds of six generations $\left(\mathrm{P}_{1}, \mathrm{P}_{2}, \mathrm{~F}_{1}, \mathrm{~F}_{2}, \mathrm{BC}_{1}\right.$, and $\left.\mathrm{BC}_{2}\right)$ of four crosses were obtained from the Oilseed section of Narendra Deva University of Agriculture and Technology, Faizabad. The six generations of four crosses were sown in field during rabi season. Heterosis over standard variety (Hira) [standard heterosis]was calculated as given by Meredith WR, Bridge RR (1972), over better parent [heterobeltiosis] by (Fonseca and Patterson, 1968)and mid-parent [relative heterosis] by (Turner, 1953) were computed for eleven characters of four crosses $\left(\mathrm{F}_{1} \mathrm{~s}\right)$ viz., NDL- 2004-05 X GS-234, NDL-2004-05 X A-95 B, NDL2004-05 X TL-27, NDL- 2004$05 \mathrm{X}$ TL-11obtained from crossing of the five parents viz., NDL 2004-05, GS-234, A-95 B, TL- 27 and TL-11. The cause of decrease in fitness and vigor i.e. Inbreeding depression was estimated in per cent with the help of $F_{1}$ and $F_{2}$ populations of the each four crosses.

\section{Results and Discussion}

As evident in Table 1, significant positive heterosis over standard variety was observed for days to $50 \%$ flowering (Cross I, II and IV), number of primary branches per plant (Cross I, III and IV), number of secondary branches per plant in all crosses, number of capsules per plant in all crosses, number of seeds per capsule in all crosses, biological yield per plant (cross I and II), 1000-seed weight (Cross I, III and IV) and seed yield per plant (cross I, II and III). Nimit et al., (2015) found significant positive standard heterosis for seed yield per plant. And significant negative heterosis over standard variety was observed for plant height in cross I, plant height and number of primary branches per plant in cross II, plant height in cross III, plant height and biological yield per plant in cross IV.

Significant and positive heterosis over better parent was observed for days to $50 \%$ flowering in cross I, II and IV; days to maturity in cross III; plant height in all crosses, number of primary branches per plant in cross I and III; number of secondary branches per plant cross I, II and III; number of capsules per plant in cross II; number of seeds per capsule in cross I; biological yield per plant in cross I, II and III; 1000-seed weight in cross II, III and IV and seed yield per plant in cross I, II and III. Whereas negative and significant heterobeltiosis was observed for days to $50 \%$ flowering in cross III same result was found by Tak and Gupta (1993); days to maturity in cross I; number of primary branches per plant in cross II; number of capsules per plant in cross III and IV; number of seeds per capsule in cross II and IV; harvest index in all crosses and 1000-seed weight in cross I, as given in Table 2 .

In Table 3 results of heterosis over mid-parent are shown which indicate positive and significant heterosis over mid parent was observed for days to $50 \%$ flowering in cross I, II and IV; days to maturity in cross II, III and IV; plant height in all crosses; number of primary branches per plant in cross I, III and IV; number of secondary branches per plant in all crosses; number of capsules per plant in cross I and II; number of seeds per plant in cross I and III; biological yield per plant in all 
crosses; 1000-seed weight in cross II, III and IV; seed yield per plant in cross I, II and III.

Reports on high heterosis for characters such as yield are also available in literature (Verma and Mahto (1996); Chandrashekhar and Rahman (2001); Kumar et al., (2014); Vikas Pali Nandan Mehta (2014) and Ratanaparkhi et al., (2004).

Table.1 Heterosis over standard variety (\%) for 11 metric traits in cross I- IV

$*$, ** Significant at $5 \%$ and $1 \%$ level of probability, respectively

\begin{tabular}{|c|c|c|c|c|}
\hline Characters & Cross I & Cross II & Cross III & Cross IV \\
\hline Days to $50 \%$ flowering & $11.606 * *$ & $13.565 * *$ & 7.493 & $9.452 * *$ \\
\hline Days to maturity & $5.714 * *$ & $7.383 * *$ & $8.792 * *$ & $8.636 * *$ \\
\hline Plant height (cm) & $-10.484 * *$ & $-5.725 * *$ & $-12.451 * *$ & $-17.262 * *$ \\
\hline $\begin{array}{l}\text { Number of primary branches per } \\
\text { plant }\end{array}$ & $24.490 * *$ & $-23.469 * *$ & $25.510 * *$ & $17.347 * *$ \\
\hline $\begin{array}{l}\text { Number of secondary branches } \\
\text { per plant }\end{array}$ & $31.808 * *$ & $70.481 * *$ & $32.723 * *$ & $23.570 * *$ \\
\hline Number of capsules per plant & $51.094 * *$ & $33.125 * *$ & $16.484 * *$ & $11.094 * *$ \\
\hline Number of seeds per capsule & $80.000 * *$ & $40.000 * *$ & $54.400 * *$ & $40.00 * *$ \\
\hline Biological yield per plant (g) & $20.110 * *$ & $19.890 * *$ & 2.948 & $-5.014 *$ \\
\hline Harvest index (\%) & 0.967 & $1.768 * *$ & $14.553 * *$ & $5.864 * *$ \\
\hline 1000-seed weight (g) & $15.951 * *$ & 33.552 & $22.209 * *$ & $15.276 * *$ \\
\hline Seed yield per plant (g) & $19.406 * *$ & $29.703 * *$ & $27.327 * *$ & 3.960 \\
\hline
\end{tabular}

Table.2 Heterosis over better parent (\%) for 11 metric traits in cross I-IV

$*$, ** Significant at $5 \%$ and $1 \%$ level of probability, respectively

\begin{tabular}{|c|c|c|c|c|}
\hline Characters & Cross I & Cross II & Cross III & Cross IV \\
\hline Days to $50 \%$ flowering & $2.151 *$ & 0.738 & $-3.728 * *$ & 0.495 \\
\hline Days to maturity & $-1.603 * *$ & -0.097 & $1.066 * *$ & 0.265 \\
\hline Plant height (cm) & $7.228 * *$ & $2.458 * *$ & $9.622 * *$ & $4.855^{* *}$ \\
\hline $\begin{array}{l}\text { Number of primary branches } \\
\text { per plant }\end{array}$ & $24.490 * *$ & $-28.571 * *$ & $21.182 * *$ & 5.05 \\
\hline $\begin{array}{l}\text { Number of secondary branches } \\
\text { per plant }\end{array}$ & $8.271 * *$ & $39.252 * *$ & $8.007 * *$ & -1.818 \\
\hline Number of capsules per plant & 1.045 & $2.899 * *$ & $-10.397 * *$ & $-13.818 * *$ \\
\hline Number of seeds per capsule & $20.968 * *$ & $-8.377 * *$ & 1.047 & $-5.405^{*}$ \\
\hline Biological yield per plant (g) & $27.485 * *$ & $25.599 * *$ & $8.100 * *$ & 2.193 \\
\hline Harvest index (\%) & $-9.545 * *$ & $-15.296 * *$ & $-1.251 *$ & $-11.876^{* *}$ \\
\hline 1000-seed weight (g) & $-11.682 * *$ & $14.497 * *$ & $9.511 *$ & $9.117 * *$ \\
\hline Seed yield per plant (g) & $14.857 *$ & $24.526^{* *}$ & $18.090 * *$ & -3.226 \\
\hline
\end{tabular}


Table.3 Heterosis over mid-parent (\%) for 11 metric traits in cross I- IV

\begin{tabular}{|c|c|c|c|c|}
\hline Characters & Cross I & Cross II & Cross III & Cross IV \\
\hline Days to $50 \%$ flowering & $2.820 * *$ & $2.952 * *$ & $-2.249 * *$ & $1.085 * *$ \\
\hline Days to maturity & $-0.893 * *$ & $0.623 * *$ & $1.287 * *$ & $0.787 *$ \\
\hline Plant height (cm) & $10.409 * *$ & $10.726 * *$ & $10.540 * *$ & $6.739 * *$ \\
\hline $\begin{array}{l}\text { Number of primary } \\
\text { branches per plant }\end{array}$ & $29.787 * *$ & $-25.373 * *$ & $32.615 * *$ & $11.111 * *$ \\
\hline $\begin{array}{l}\text { Number of secondary } \\
\text { branches per plant }\end{array}$ & $12.610 * *$ & $45.650 * *$ & $12.403 * *$ & $4.348 * *$ \\
\hline $\begin{array}{l}\text { Number of capsules per } \\
\text { plant }\end{array}$ & $8.287 * *$ & $3.713 * *$ & $-4.208 * *$ & $-7.872 * *$ \\
\hline Number of seeds per capsule & $22.283 * *$ & $-7.162 *$ & $5.177^{*}$ & $-5.149 *$ \\
\hline Biological yield per plant (g) & $34.423 * *$ & $38.049 * *$ & $18.110 * *$ & $11.496 * *$ \\
\hline Harvest index $(\%)$ & $-7.791 * *$ & $-11.934 * *$ & 0.899 & $-7.944 * *$ \\
\hline 1000-seed weight $(\mathrm{g})$ & -0.526 & $23.655^{* *}$ & $14.647 * *$ & $10.108 * *$ \\
\hline Seed yield per plant (g) & $21.757 * *$ & $25.901 * *$ & $23.476 * *$ & -1.130 \\
\hline
\end{tabular}

$*$,** Significant at $5 \%$ and $1 \%$ level of probability, respectively

Table.4 Inbreeding depression $(\%)$ in $\mathrm{F}_{2}$ over $\mathrm{F}_{1}$ for 11 metric traits in cross I-IV

\begin{tabular}{|c|c|c|c|c|}
\hline Characters & Cross I & Cross II & Cross III & Cross IV \\
\hline Days to $50 \%$ flowering & $3.02 * *$ & $2.71 * *$ & -0.22 & 0.58 \\
\hline Days to maturity & $-1.43 * *$ & 0.04 & 0.24 & 0.14 \\
\hline Plant height $(\mathrm{cm})$ & $6.86 * *$ & $8.12 * *$ & $8.46 * *$ & $3.72 * *$ \\
\hline $\begin{array}{l}\text { Number of primary branches per } \\
\text { plant }\end{array}$ & $22.95 * *$ & $16.00 *$ & $22.76 * *$ & $13.91 *$ \\
\hline $\begin{array}{l}\text { Number of secondary branches } \\
\text { per plant }\end{array}$ & $3.81 *$ & $18.65 * *$ & $4.65 * *$ & $4.63 * *$ \\
\hline Number of capsules per plant & $6.92 *$ & $10.62 * *$ & $13.81 * *$ & 3.93 \\
\hline Number of seeds per capsule & 6.66 & $14.85 * *$ & 8.29 & 5.71 \\
\hline Biological yield per plant (g) & 1.56 & $7.51 * *$ & 4.22 & $9.22 * *$ \\
\hline Harvest index $(\%)$ & $18.20 * *$ & $-4.60 * *$ & $15.92 * *$ & 0.50 \\
\hline 1000-seed weight $(\mathrm{g})$ & 1.21 & $10.63 * *$ & 5.77 & 2.92 \\
\hline Seed yield per plant (g) & 13.26 & 3.05 & $20.68 * *$ & 10.66 \\
\hline
\end{tabular}

$*$, ** Significant at $5 \%$ and $1 \%$ level of probability, respectively

Inbreeding depression estimated from $\mathrm{F}_{2}$ over $\mathrm{F}_{1}$, was noted positive and significant for days to $50 \%$ flowering in cross I and II; plant height in all four crosses; number of primary branches per plant in all four crosses; number of secondary branches per plant in all four crosses; number of capsules per plant in cross
I, II and III; number of seeds per capsule in cross II; biological yield per plant in cross II and IV; harvest index in cross I, III and IV; 1000 -seed weight in cross III and IV and seed yield per plant in cross III; same results were substantiated by few other authors Rao and Singh (1983), Saraswat et al., (1993), Rao 
(2006) for 1000 seed weight, seed yield per plant and capsules per plant. Whereas negative and significant inbreeding depression were found for days to maturity in cross I and harvest index in cross II as shown in Table 4.

For days to $50 \%$ (cross I, II and IV); days to maturity (cross I); plant height (cross I and III); number of primary branches per plant (cross I, II and III); number of capsules per plant (cross II and III); number of seeds per capsule (cross II and III); biological yield (cross II and IV); harvest index (cross II); and seed yield per plant (cross III) had significant or highly significant and positive standard heterosis, heterobeltiosis, mid-parent heterosis and inbreeding depression. Rao et al., (2001), Swarankar et al., (2003) and Sharma et al., (2005), have found positive estimates of inbreeding depression in most of the traits studied by them.

Nature and magnitude of heterosis and inbreeding depression varied with crosses, characters as well as environments. Considering the very high degree of heterosis in desirable direction and importance of nonadditive genetic variance for yield and yield contributing components; Cross II (NDL2004-05 x A-95 B) and cross III (NDL-2004$05 \times$ TL-27) were identified better specific cross combination to be used for heterosis breeding programme. However, predominant role of non-additive gene action in expression of heterosis accompanied by inbreeding depression for these traits discussed above would render difficulty in the fixation and sustainability of heterotic effects in later generations.

\section{References}

Cavalli LL. 1952. An analysis of linkage in quantitative inheritance, In: Quantitative inheritance (ECR Rieve and $\mathrm{CH}$
Waddington et al., eds.) London pp. 135-144.

Chandrashekhar, Mahto and Rahman MH. 2001. Heterosis for yield and yield components in linseed (Linum usitatissimum L.). J. Res.Birsa Agric. Univ., 13 (2): 189-191.

Fonseca S, Patterson F 1968. Hybrid vigour in seven parent diallel crosses in common winter wheat (Triticum aestivum L.). Crop Sciences8: 85-95.

Kiran, Kanojia RK 2014. Heterosis and inbreeding depression in linseed, (Linum usitatissimum L.) New Agriculturist 25(2): $188-188$.

Kumar, S. Kumar, R. Kumar, S. Singh, H. Singh, S. K. 2014. Estimation of heterosis in linseed (Linum usitatissimum L.). Inter. J. Agric. Sci., 10(1):356-359.

Meredith WR, Bridge RR 1972. Heterosis and geneaction in cotton, (Gossypium hirsutum). Crop Sciences 12: 304-310.

NimitKumar and Satish Paul 2015. Genetic analysis of yield and yield contributing traits in linseed (Linum usitatissimum L.) The Bioscan 10(4): 1951-1955.

Rao SK, Singh SP 1983. Heterosis and inbreeding depression in linseed. Indian J. Agric. Sci. 53(6): 409-417.

Rao SS. 2006. Heterosis and inbreeding depression in linseed (Linum usitatissimum L.). J. Oilseeds Res., 23 (2): 187-190.

Rao, S. S. Rede, A. P. Chandrakar, P. K. 2011. Heterosis and inbreeding depression in linseed. Mysore J. Agric. Sci., 35(1):16-19.

Ratanaparkhi RD, Dudhe MY, Gawande ND and Bhongle SA. 2004. Heterosis in relation to combining ability effects in linseed. Annals of Plant Physiology, 18 (2): 182-186.

Saraswat AV, Kumar S, Verma MM, VirkDS, Chahal GS 1993. Heterosis and inbreeding depression in some early 
hybrids of linseed. In: Heterosis Breeding in Crop Plants. Theory and Application: Short Communications. Symposium, Ludhiana, 23-24 February 1993, pp 52-53.

Sharma R, Tiwari SK, Singh P and Ramakant. 2005. Heterobeltiosis and inbreeding depression in linseed. Agric. Sci. Digest, 25(1): 35-37.

Swarnkar, S.K. Singh, P. and Srivastava, R.L. 2003.Combining ability analysis in linseed (Linum usitatissimum L.). Progressive Agric., 3 (1-2): 103-106.
Tak G.M. and Gupta V.P. 1993. Studies on heterosis in linseed. Indian J. Agric. Res., 27 (4): 181-184.

Verma AK and Mahto J.L. 1996. Hybrid vigor in linseed (Linum usitatissimum L.) for yield and yield attributes under rain-fed and irrigated environments. $J$. Trop. Agric., 34 (1): 54-57.

Vikas Pali Nandan Mehta 2014. Combining ability and heterosis for seed yield and it's attributes in linseed (Linum usitatissimum L.). The Bioscan, 9(2 Supplement):701-706.

\section{How to cite this article:}

Aarti Sharma, Akanksha Srivastava and Chauhan, M.P. 2018. Heterosis and Inbreeding Depression in Linseed (Linum usitatissimum L.). Int.J.Curr.Microbiol.App.Sci. 7(02): 554-559. doi: https://doi.org/10.20546/ijcmas.2018.702.070 